\title{
Molecular Diagnosis of Taenia saginata Tapeworms from Two Residents of Northern Cambodia
}

\author{
Taehee Chang', Bong-Kwang Jung1', Woon-Mok Sohn², Sooji Hong', Hyejoo Shin', Seungwan Ryoo', \\ Jeonggyu Lee', Keon Hoon Lee', Virak Khieu³, Rekol Huy³, Jong-Yil Chai ${ }^{1,4, * *}$ \\ 1Institute of Parasitic Diseases, Korea Association of Health Promotion, Seoul 07649, Korea; ${ }^{2}$ Department of Parasitology and Tropical Medicine, \\ and Institute of Health Sciences, Gyeongsang National University College of Medicine, Jinju 52727, Korea; ${ }^{3}$ National Center for Parasitology, \\ Entomology and Malaria Control, Phnom Penh, Cambodia; ${ }^{4}$ Department of Tropical Medicine and Parasitology, Seoul National University College of \\ Medicine, Seoul 03080, Korea
}

\begin{abstract}
Taenia saginata infection has seldom been reported in Cambodia. In this study, we performed a survey of intestinal parasites in 1,156 residents of Preah Vihear and Stung Treng Provinces in 2018. The results revealed that 26 (2.4\%) cases were positive for Taenia spp. eggs. In order to obtain the strobilae of the tapeworms, 2 patients in Preah Vihear were treated with praziquantel and purged with magnesium salts. The proglottids expelled after the medication were morphologically and molecularly analyzed to determine the species. The main uterine lateral braches in gravid proglottids were $>15$ in number suggesting that they are either T. saginata or Taenia asiatica. The sequences of the mitochondrial cytochrome c oxidase subunit 1 (cox1) gene and 2 nuclear loci, elongation factor-1 alpha (ef1) and ezrin-radixin-moesin-like protein (elp), were identical to the sequences of $T$. saginata available in GenBank but distant from Taenia solium, $T$. asiatica, and T. saginata-T. asiatica hybrid. This is the first report of the presence of $T$. saginata in the northern part of Cambodia bordering Lao PDR based on a molecular confirmation.
\end{abstract}

Key words: Taenia saginata, cox1, ef1, elp, molecular diagnosis, Cambodia

Taenia saginata, Taenia asiatica, and Taenia solium are 3 tapeworm species that can cause zoonotic infections in humans. They have unique life cycles, with humans as the only definitive host [1]. Beef is the infection source for T. saginata, whereas T. asiatica and T. solium infections are contracted by pork. The distribution of human taeniases is worldwide, and T. saginata is the most prevalent species [2].

Little has been known about human Taenia tapeworm infections in Cambodia with the exception of 2 studies reported in 2011 and 2014 [3,4]. According to the reports, fecal examinations of residents in Koh Kong Province [3] and 18 nationwide provinces [4] revealed the egg positive rate of Taenia spp. to be $1.5 \%(43 / 2,824)$ and $0.4 \%(115 / 32,201)$, respectively. In Koh Kong Province, eggs of Taenia spp. from 21 individuals were molecularly analyzed, and T. saginata $(\mathrm{n}=19)$ and T. solium $(\mathrm{n}=2)$ were identified by cox1 sequencing and multiplex PCR

- Received 31 January 2020, revised 7 April 2020, accepted 7 April 2020.

* Corresponding author (cjy@snu.ac.kr)

(c) 2020, Korean Society for Parasitology and Tropical Medicine

This is an Open Access article distributed under the terms of the Creative Commons Attribution Non-Commercial License (https://creativecommons.org/licenses/by-nc/4.0) which permits unrestricted non-commercial use, distribution, and reproduction in any

medium, provided the original work is properly cited.
[3]. However, no other information is available regarding the species of Taenia in other localities of Cambodia. In this study, we molecularly confirmed $T$. saginata proglottids expelled from 2 residents after praziquantel treatment and purging in a northern part of Cambodia.

In May 2018, the Institute of Parasitic Diseases, Korea Association of Health Promotion (KAHP), in cooperation with the National Center for Parasitology, Entomology and Malaria Control, Cambodia, conducted a survey on intestinal parasitic infections in 2 northern provinces (5 villages each), Preah Vihear and Stung Treng (IRB no. 099NECHR, approved by National Ethics Committee for Health Research, Cambodia). A total of 1,156 fecal samples were collected from the residents and examined by the Kato-Katz thick smear method. The results revealed that the overall egg positive rate of Taenia spp. was $2.4 \%(26 / 1,156) ; 1.7 \%$ (6/359) in Preah Vihear and 2.5\% (20/797) in Stung Treng (Table 1). A small village named Kampong Sangkae located in the northeastern part of Preah Vihear and bordered with Lao PDR showed a fairly high prevalence $(3.4 \%, 3 / 89)$ of Taenia spp. eggs. This village was selected for further analysis of Taenia tapeworms in this study.

Two egg positive cases from this village were treated with 10- 
$15 \mathrm{mg} / \mathrm{kg}$ praziquantel (Shinpoong Pharm. Co., Seoul, Korea) followed by purging with $30-40 \mathrm{~g} \mathrm{MgSO}_{4}$. The 2 tapeworm strobilae (1 was with scolex) (Fig. 1A, B) discharged from the 2 cases were stored in 70\% ethanol until morphological and molecular analyses. The scolex revealed 4 suckers but no recognizable rostellum nor hooklets (Fig. 1B). Several proglottids from each of the 2 cases were fixed in $10 \%$ formalin and stained with Semichon's acetocarmine, and morphologically observed using a light microscope. They were identified as either $T$. saginata or $T$. asiatica since they had $>15$ main uterine

Table 1. Infection status of tapeworms in 2 northern provinces of Cambodia

\begin{tabular}{llcc}
\hline Province & \multicolumn{1}{c}{ Village } & $\begin{array}{c}\text { No. of people } \\
\text { examined }\end{array}$ & $\begin{array}{c}\text { No. of Taenia } \\
\text { spp. egg positive } \\
\text { cases (\%) }\end{array}$ \\
\hline Preah Vihear & Kampong Pou & 52 & $0(0.0)$ \\
& Kampong Chey & 42 & $2(4.8)$ \\
& Kampong Sangkae & & $3(3.4)$ \\
& Kampong Sralau & 74 & $0(0.0)$ \\
& Kampong Sami & 50 & $1(2.0)$ \\
Stung Treng & Subtotal & 359 & $6(2.0)$ \\
& O' Chay & 125 & $6(4.8)$ \\
& Kanhchanh Tuek & 114 & $4(3.5)$ \\
& Ti Team & 93 & $0(0.0)$ \\
& Srae Russei & 204 & $4(2.0)$ \\
Total & Peam Khes & 261 & $6(2.3)$ \\
& Subtotal & 797 & $20(2.5)$ \\
& & 1,156 & $26(2.4)$ \\
\hline
\end{tabular}

${ }^{a}$ The village where residents were recruited for praziquantel treatment and purging to recover adult tapeworms. lateral branches filled with eggs (Fig. 1C) [5].

The genomic DNA of each tapeworm segment was extracted using the DNeasy Blood \& Tissue kit (QIAGEN, Hilden, Germany) following the manufacturer's instructions. PCR amplification and sequencing of mitochondrial cytochrome $c$ oxidase ( cox1, 1,620 bp), nuclear elongation factor-1 $\alpha$ (ef1, 1,090 bp), and nuclear ezrin-radixin-moesin (ERM)-like protein (elp, $1,160 \mathrm{bp}$ ) genes were performed on each tapeworm sample with primers and conditions reported in a previous study [6]. A phylogenetic tree of cox1 gene constructed from the representative selection of sequences available in GenBank, using the maximum-likelihood method available in MEGA and employing Tamura-nei model of nucleotide substitution with 1,000 bootstrap replications, showed that our samples were both identical with T. saginata (Fig. 2). The sequence homology (cox1) was $99.7 \%$ with T. saginata and $94.8-95.2 \%$ with $T$. asiatica. In addition, our samples contained the nuclear loci alleles ef $1 \mathrm{C} / \mathrm{ef} 1 \mathrm{C}$ and elpC/elpC, which are homozygous for $\mathrm{T}$. saginata based on the interpretation using Sanger chromatogram analysis (Table 2) [6]. This demonstrates that our samples are not a hybrid between T. saginata and T. asiatica but 'pure T. saginata'.

Human taeniases are known to be endemic in Southeast Asia, including Myanmar [7] and Lao PDR [8]. In Cambodia, a few previous surveys reported low-grade prevalence of Taenia spp. among the residents in several provinces $[3,4]$. Molecular studies on the species were reported in a paper in which the genom-
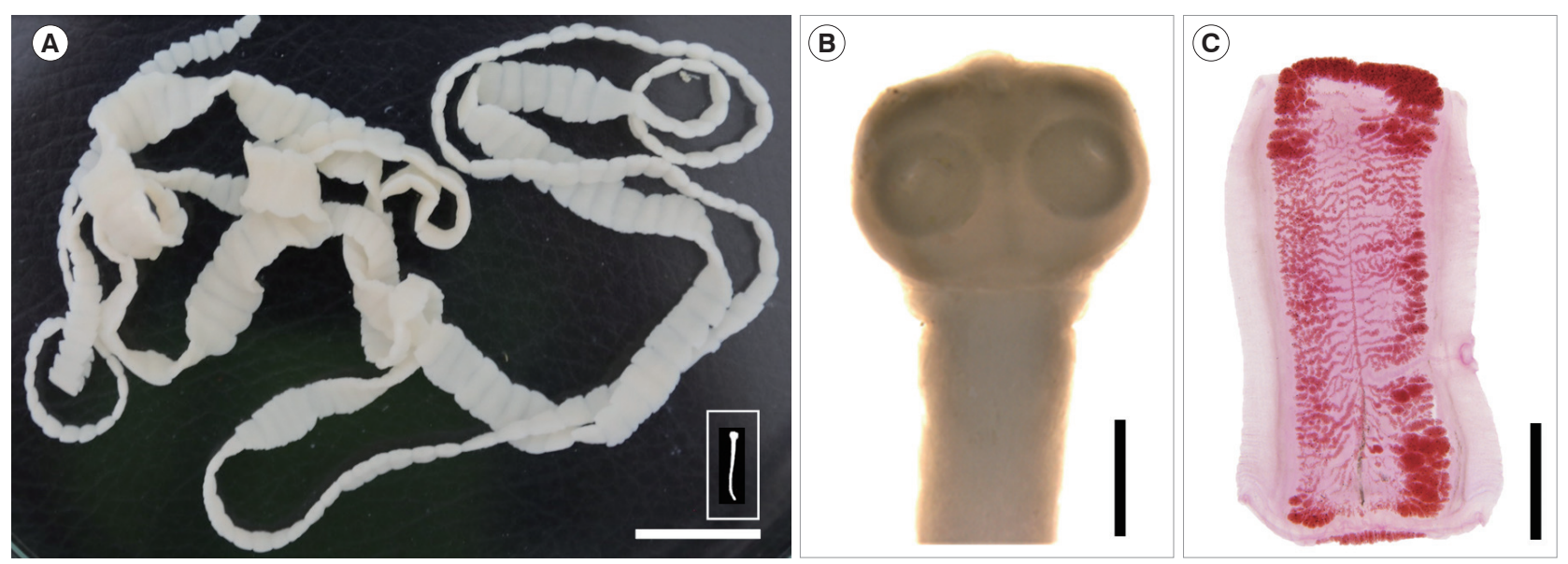

Fig. 1. (A) A complete tapeworm strobila, including the scolex (inset), of Taenia saginata discharged from a resident in Kampong Sangkae village, Preah Vihear Province, Cambodia. Scale bar $=2 \mathrm{~cm} .(B, C)$ Enlarged views of the scolex and a gravid proglottid taken with a stereomicroscope (Leica, Wetzlar, Germany). Morphological characteristics of the unarmed scolex with no distinct rostellum (B) and the high number (>15) of main uterine lateral branches $(\mathrm{C})$ designated the tapeworm as either T. saginata or T. asiatica and far from T. solium. Scale bar $=1 \mathrm{~mm}$ in (B) and $3 \mathrm{~mm}$ in (C). 


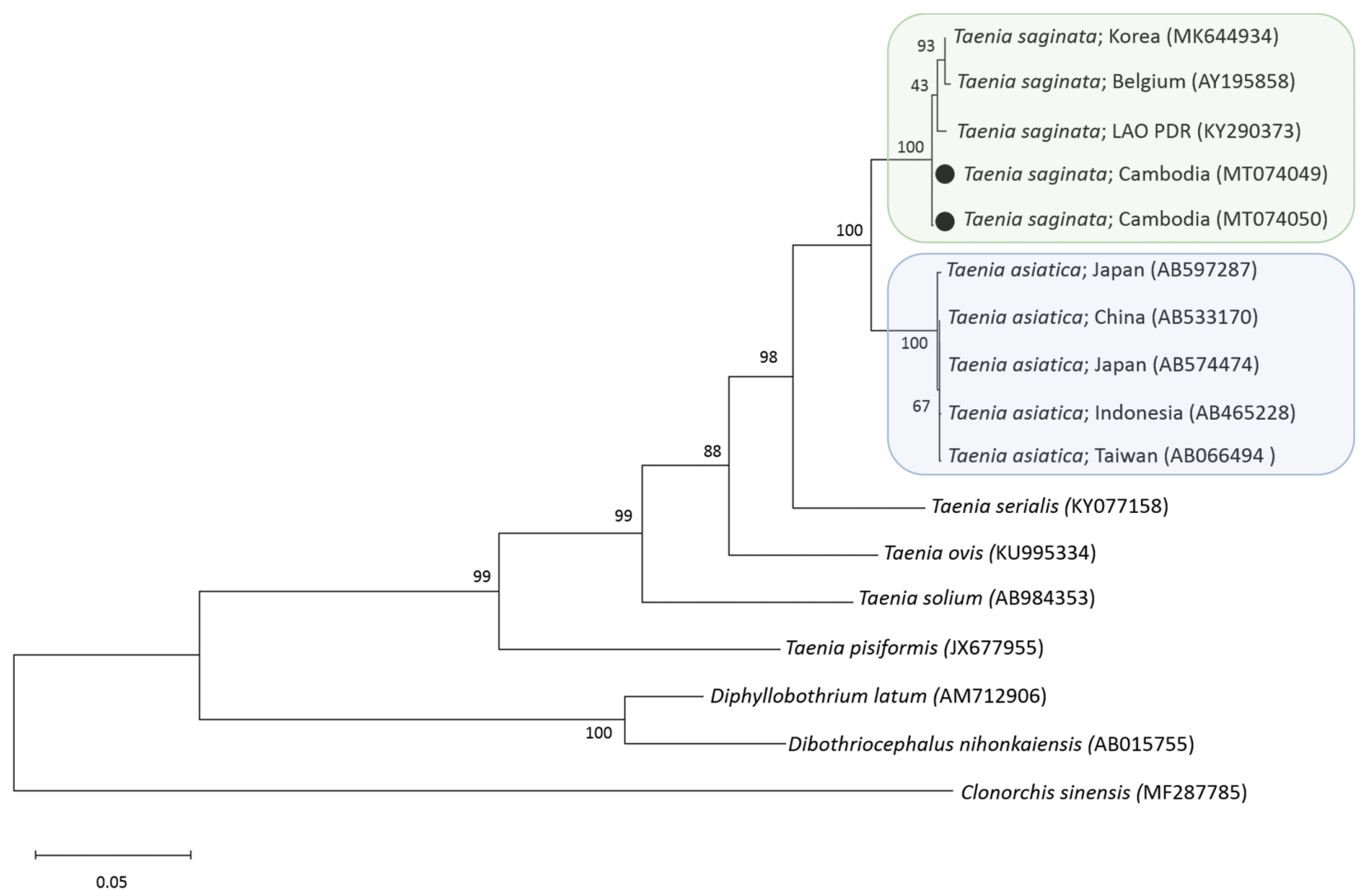

Fig. 2. A phylogenetic tree of 2 tapeworm samples obtained in this study in relation to tapeworm species drawn with cox 1 DNA sequences in GenBank. Black dots indicate 2 samples identified in this study. Clonorchis sinensis was used as an outgroup. Scale bar indicates nucleotide substitutions per site.

Table 2. Genotype of tapeworm samples from 2 patients

\begin{tabular}{lccc}
\hline Patient no. & $\begin{array}{c}\text { mtDNA type } \\
\text { (cox1) }\end{array}$ & $\begin{array}{c}\text { Genotype a at ef } 1 \\
\text { locus }\end{array}$ & $\begin{array}{c}\text { Genotype a } \text { at elp } \\
\text { locus }\end{array}$ \\
\hline 1 & T. saginata & $\begin{array}{c}\text { ef1C/ef1C } \\
\text { (T. saginata) }\end{array}$ & $\begin{array}{c}\text { elpC/elpC } \\
\text { (T. saginata) }\end{array}$ \\
& T. saginata & $\begin{array}{c}\text { ef } 1 \mathrm{C} / \mathrm{ef} 1 \mathrm{C} \\
\text { (T. saginata) }\end{array}$ & $\begin{array}{c}\text { elpC/elpC } \\
\text { (T. saginata) }\end{array}$ \\
\hline
\end{tabular}

aThe allele types of these samples were analyzed following the previous study [6].

ic DNA was extracted from eggs collected from the feces [3]. In our study, we obtained gravid proglottids from 2 patients and observed that they had more than 15 main uterine lateral branches being consistent with T. saginata or T. asiatica but not with T. solium. To determine whether they are T. saginata or $T$. asiatica, it was necessary to perform molecular analyses [2].

Interestingly, hybrid descendants of T. saginata and T. asiatica were reported from humans in Thailand [6] and Lao PDR [8]. Therefore, we conducted molecular analyses of cox 1 , ef1, and elp genes to rule out this hybrid issue. The cox 1 sequences re- vealed high homologies with T. saginata but low homologies with T. asiatica. The nuclear gene ef1 is known to have 3 alleles (ef1A, ef1B, and ef1C), and another nuclear gene elp has 4 alleles (elpA, elpB, elpC, and elpD); T. saginata has only 1 ef 1 allele (ef1C) and 3 elp alleles (elpA, elpC, and elpD), whereas $\mathrm{T}$. asiatica has 2 ef1 alleles (ef1A and $e f 1 \mathrm{~B}$ ) and 2 elp alleles (elpA and elpB) [6]. Our samples had ef1C and elpC alleles, and thus we could confirm them not a hybrid of the 2 species but pure T. saginata.

The geographical distribution of 3 human Taenia spp. is closely related to cultural characteristics of the people, which include the traditional food habit of consuming undercooked meat, including beef and pork, infected with viable metacestodes [8]. Our study suggests the necessity of continued surveillance of human Taenia tapeworm infections in Cambodia.

\section{ACKNOWLEDGMENTS}

We appreciate the staff of the National Center for Parasitolo- 
gy, Entomology and Malaria Control, Ministry of Health, Phnom Penh, Cambodia, and the Preah Vihear and Stung Treng Provincial Health Department, Cambodia for their help in this survey.

\section{CONFLICT OF INTEREST}

We have no conflict of interest related to this work.

\section{REFERENCES}

1. Chai JY. Human taeniasis in the Republic of Korea: hidden or gone? Korean J Parasitol 2013; 51: 9-17.

2. Eom KS, Rim HJ. Epidemiological understanding of Taenia tapeworm infections with special reference to Taenia asiatica in Korea. Korean J Parasitol 2001; 39: 267-283.

3. Jeon HK, Yong TS, Sohn WM, Chai JY, Hong SJ, Han ET, Jeoung HG, Chhakda T, Sinuon M, Socheat D, Eom KS. Molecular identification of Taenia tapeworms by cox1 gene in Koh Kong, Cambodia. Korean J Parasitol 2011; 49: 195-197.

4. Yong TS, Chai JY, Sohn WM, Eom KS, Jeoung HG, Hoang EH,
Yoon CH, Jung BK, Lee SH, Sinuon M, Socheat D. Prevalence of intestinal helminths among inhabitants of Cambodia (20062011). Korean J Parasitol 2014; 52: 661-666.

5. Mayta H, Talley A, Gilman RH, Jimenez J, Verastegui M, Ruiz M, Garcia HH, Ganzalez AE. Differentiating Taenia solium and Taenia saginata infections by simple hematoxylin-eosin staining and PCR-restriction enzyme analysis. J Clin Microbiol 2000; 38: 133137.

6. Okamoto M, Nakao M, Blair D, Anantaphrui MT, Waikagul J, Ito A. Evidence of hybridization between Taenia saginata and Taenia asiatica. Parasitol Int 2010; 59: 70-74.

7. Won EJ, Jung BK, Song H, Kim MS, Kim HS, Lee KH, Kim MJ, Shin MG, Shin JH, Suh SP, Hong SJ, Sohn WM, Htoon TT, Tin $\mathrm{HH}$, Chai JY. Molecular diagnosis of Taenia saginata tapeworm infection in 2 schoolchildren, Myanmar. Emerg Infect Dis 2018; 24: 1156-1158.

8. Sato MO, Sato M, Yanagida T, Waikagul J, Pongvongsa T, Sako Y, Sanguankiat S, Yoonuan T, Kounnavang S, Kawai S, Ito A, Okamoto M, Moji K. Taenia solium, Taenia saginata, Taenia asiatica, their hybrids and other helminthic infections occurring in a neglected tropical diseases' highly endemic area in Lao PDR. PLoS Negl Trop Dis 2018; 12: e0006260. 